\title{
Management development needs of library managers belonging to Gauteng and Environs Library and Information Consortia (GAELIC) in South Africa
}

\author{
Solomon Bopape \\ University of the North Library \\ Private Bag XIII2 Sovenga 0727 South Africa \\ solomonb@unorth.ac.za
}

Received:24 $24^{\text {th }}$ February 2003

Revised: I/ ${ }^{\text {th }}$ June 2004

This article is based on the Masters dissertation that was submitted to the Department of Information Studies, University of Pretoria. The changing social and political environments in South Africa have created a lot of complex and challenging opportunities for the management of human resources in most organizations. In library and information service organizations, managers have received little or no training in human resources management. In order to establish what the training and development needs of managers in academic libraries in performing human resource management activities and tasks are, a survey by means of a questionnaire based on the Graham and Mihal model was conducted, using six South African university libraries, from the Gauteng and Environs Library and Information consortium (GAELIC). The results of this study or research paper showed that most library managers in the selected academic libraries need training and development in human resource management activities and tasks, especially those related to utilization and development of staff. They need to know more about conducting performance appraisals, motivating staff, improving staff relations and delegating responsibilities. They also showed a need for training and development on activities and tasks related to managing labour and employment relations. This includes understanding employment legislation, communicating with employees, improving and maintaining good working conditions as well as maintaining discipline. Although few library managers indicated the need for training and development in tasks related to human resource planning, some indicated they need training and development in tasks related to human resource provision such as selecting and appointing suitable library employees. Programmes that address these needs must be developed in South Africa. The programmes must be designed to equip library managers with skills and competencies that will enable library managers to manage staff effectively.

Keywords: Management development needs; library managers; library human resource management; GAELIC region

\section{Introduction}

It is generally accepted that people working in an organization are its most important asset and crucial to the success of that organization. Ultimately, human resources should be managed as effectively as the other resources of the organization. This aspect of management has received increasing emphasis in most organizations today. To be an effective manager in this aspect, however requires continuous training and development. In this study the specific training and development needs of library managers in performing human resource management activities and tasks were investigated by means of a questionnaire based on the Graham and Mihal (1986:38-42) model of identifying management development needs. Library managers attached to six academic libraries belonging to the Gauteng and Environs Library and Information Consortium (GAELIC) were selected for the study.

GAELIC is the first and major project of FOTIM (Foundation of Tertiary Institutions of the Northern Metropolis). It was founded in 1996 with the aim of promoting cooperation and collaboration amongst libraries and information services in the Gauteng region in order to fully utilize and develop the information resources for the purpose of promoting education, research and life long learning. This could be achieved through sharing of information, sharing of expertise, joint workshops, enhanced document delivery, shared cataloguing and the joint purchasing of full text databases. Five key strategies that provide the framework for the project were identified. Providing skills required for human resource development was also identified as one of the five key strategies for the achievement of the project (GAELIC Profile: 2002). This has created more challenges to the management and development of human resources in libraries and information services organizations in the region.

The other challenges created by social and political developments in South Africa that have an important influence on the ways in which human resources in organizations are managed are:

- Democratization of the workplace through introduction of laws such as Labour Relations Act (No. 66 of 1995), Basic Conditions of Employment Act (No. 75 of 1997), Employment Equity Act (No. 55 of 1998), Skills Development Act (No. 97 of 1998), as well as values enshrined in the Bill of Rights contained in the R.S.A. Constitution (Act 108 of 1996). Organizational managers must observe these laws at all stages of staff appointment, utilization, development and

I. Solomon Bopape is a Law Librarian at the University of the North Library. 
maintenance.

- Evolving of concepts such as affirmative action, employee empowerment and employment equity resulted in management of diversity of cultures in most organizations.

- Restructuring of the organizations as well as development of new management techniques also make human resource management more complex and challenging than ever before.

- A revolution of information and communication technologies taking place in the world results in new training and development needs for all employees.

- The spread of HIV / AIDS was also mentioned by Yadavalli (1999:25) as a serious threat to organizational human resources and productivity in the workplace. To address this threat, careful human resource planning is necessary in virtually every organization. Activities required range from the development of appropriate employee benefits structures, health care and support, training and education in every organization.

Dealing with these challenges involves different competencies and skills at different levels of management in the organization and it requires new ways of thinking, solving problems, communicating with, developing, motivating and maintaining staff. Erasmus (1997:21) emphasized that organizational managers are compelled to make certain mindset changes to ensure long-term survival of their organizations. It has been found that these challenges affect not only profitmaking businesses and industries, but also non-profit organizations such as academic or university libraries. As academic libraries strive to provide information services to their clientele, people occupying management positions in those libraries are required to plan, recruit, select and appoint people who are willing to carry out day-to-day operations of the library effectively. They must motivate, persuade, manage conflicts, maintain discipline, delegate, solve problems, build teams and establish rapport with each individual within the library and information service. They must also train, coach, and develop staff and provide ongoing education and development for staff to make the best use of human resources.

Academic libraries usually do not have full-time human resource managers to oversee this part of management. Library managers on all levels have responsibilities in this regard, although they have to do it as part of their job. Even so, they need to be conversant with what is needed to manage staff effectively. Librarians seem to lack needed human resources management skills because of the following reasons:

- Library managers have been selected for their position because of their knowledge and experience in the field of library and information service. They have often served a time in a particular area of the library such as technical or information services, and have been promoted to positions of increasing responsibility, without paying attention to the human resource management skills required (McCabe and Person, 1995:95). It is only when they assume responsibility, as library managers that they have to learn these skills. This situation usually results in a trial and error approach, which is not only expensive, but counter productive.

- Kinnel(1996:209) also stated that the initial professional education for library and information science workers does not prepare them to undertake many of the complex managerial activities expected of them when they assume responsibility as library managers.

- Many librarians in management positions completed their studies a long time ago and do not remember much of they have learnt. Even if they do remember, most of the knowledge gained during their studies has since become obsolete. Continuous training and development is therefore essential.

- In most universities, human resources management activities and tasks are centralized at one human resources department for the whole organization. Most library managers therefore, tend to disregard the need for some of the human resources management activities and tasks. Some human resources management activities and tasks cannot be done from a remote location since this can lead to low morale and poor performance on the part of library staff.

- Some library managers may instinctively know how to manage people working under them, but they will also benefit from training and development in particular skills a human resource manager needs.

For this reasons, a systematic determination of the development needs of library managers to perform human resource management activities and tasks is critical. The aim of this study was to achieve the following objectives:

- to identify and measure management development needs of top, middle and lower managers in academic libraries regarding human resource management activities and tasks;

- to establish and bridge the gap that exist in management development of librarians and information workers;

- to emphasize the value of human resource management in the education and training of librarians and information workers;

- to emphasize the value of managing human resources effectively in academic libraries and information services;

- to determine which human resource management activities and tasks library managers perceive to be important and need development in;

- to recommend a basis for human resource management development for academic library managers in the region. 


\section{Literature review}

Management literature emphasizes the close link between training and development. In this research paper however, training should be seen as providing skills base from which development can take place. Training is provided for nonmanagerial employees, whereas development is associated with management (Rowley, 1995: 6). Training focuses on the technical skills that employees require for performing a specific task effectively. Development focuses on the necessary experience, skills and disposition the managers in the organization must possess (De Beer, Rossouw, Moolman, le Roux, Labuschange 1998:181). Management development refers to the preparation of managers for higher-level jobs or for possible changes in future. In the process of management development, managers are assisted in managing change and adapting to the general external and internal changes taking place in the organization. It is aimed at improving productivity, performance and achieving organizational objectives. It is a total process of preparing and providing effective managers and refining their performance today and in the future (Erasmus \& Van Dyk, 1999: 210-21I). The concept management development in this research paper is used as the process of preparing and training managers to successfully manage their subordinates, as defined by Erasmus \& Van Dyk (1999: 210).

The concept "need" can be defined as lack of essential knowledge, skills or attitudes that in turn prevent satisfactory job performance or interfere with an individual's potential for assuming different or greater responsibility (Ochai, 1985:358). A need exists when an individual or group lacks the necessary skills or knowledge to perform an assigned task satisfactorily. In this research paper attention was focused on identifying knowledge and skills that library manager's lack to effectively perform human resources management activities and tasks or to manage library staff effectively.

The literature survey that was conducted prior to this research paper revealed that Ochai (1983:357-369) conducted a similar study in university libraries in Nigeria, that is, on the management development needs of library managers. The study concentrated on four topics, namely:

- Administration

- Personnel management

- Communication

- Leadership

The study revealed that a large number of library managers in university libraries in Nigeria needed training and development on personnel management and administration. The present study wanted to establish which personnel management activities and tasks does library managers in GAELIC region of South Africa need development in. Most of the articles in the library and information field dealing with the subject of this study, expressed concern about the challenges posed by social and technological changes and the need for training and development of library human resources managers to meet those challenges (Brindley, 1987: 235-243; Corral, 1994: 209-220; 1995: 35-42; Rowley, 1995: 5-10). They emphasize that as the environment in which the libraries operate is changing, the role of the librarian also changes, requiring skills of the professional managers. This research paper was aimed at establishing and measuring the needs of library managers to meet the training and development needs of staff under them, in the changing environment. When surveying literature about management development needs in South Africa, it was clear that the topic has received vast consideration in management literature. The management development needs of library managers to perform human resources management activities and tasks have never been investigated in South Africa. Perhaps this was because human resources management was seen as relevant to business organizations only and seldom an issue for non-profit-making organizations such as academic libraries and information service organizations. Literature for this study was therefore mostly obtained from the management sciences and applied to the library and information environment.

\section{Methodology}

A structured questionnaire based on the Graham and Mihal (1986:38-42) model of identifying management development needs was used as the data collection method in this research paper. According to this model, making a list of potential training and development needs should be the first step in the needs assessment process. A list of four human resources management activities with five tasks each was therefore, compiled as follows:

- Human resources planning (including formulating human resources strategy, conducting job analysis and design, assessing human resource requirements, writing job descriptions and specifications and designing work rules and procedures);

- Human resources provision (including recruiting potential employees, evaluating recruitment process, selecting and appointing new employees, achieving equity in the selection process, introducing new employees to the library);

- Human resources utilization and development (including motivating employees, improving human relations, conducting performance appraisal, evaluating training programmes for employees and delegating responsibilities among staff);

- Managing labour and employment relations (understanding employment legislation, maintaining discipline among 
employees, handling employee grievances, communicating with employees and improving working conditions). The questionnaire was divided into five sections. Section A aimed to gather information about the demographic factors such as age, gender, level of management, experience, number of subordinates and qualifications from the respondents. These variables were included in order to determine the extent to which they influence management development needs of library managers.

Section B dealt with the degree of importance library managers attach to each human resources management tasks. In order to determine how library managers rate selected human resource management tasks, they were requested to indicate the degree of importance they attach to each human resources management task. Section $C$ looked at the specific development needs of library managers regarding human resource management tasks. In order to determine the specific development needs of library managers in performing human resources management tasks, they were also requested to indicate the degree of need for development for each task. The next step in Graham and Mihal model is to request managers to place their needs in order of priority and to link the objectives to these needs. Library managers were requested to indicate in order of priority ten $(10)$ of the most important human resource management tasks they value most and would like to develop their performance in.

In identifying management development needs, library managers were also requested to indicate skills and competencies that they need to develop or know more about, in order to manage their staff effectively in section D of the questionnaire. The list of human resources tasks selected for the purpose of this study was not as comprehensive as required by the Graham and Mihal model. Library managers were therefore also requested to make a list of human resources management activities and tasks that they feel are important and would like to know more about or improve their performance in, but which were not included in the questionnaire, in section $\mathrm{E}$. In all the sections the tasks to which the answer was "no opinion" or "not applicable" were considered to be those respondent feels he /she does not know anything about or does not fall within his /her job description. This was mentioned in the covering letter to ensure that all the questions were answered.

The research was limited to six selected university libraries belonging to the Gauteng and Environs Library and Information Consortium (GAELIC). The reason for choosing university libraries only was that they have a major role to play in supporting their parent institutions in contributing towards economic and social development of the country. Three libraries from the Historically Black Institutions and three from Historically White Institutions were selected in order to ascertain if there are significant differences in two groups of universities regarding management development of library top, middle and lower managers.

This research was also limited to the management development needs of library top, middle and lower managers. But since the university libraries selected for this study differ in size and have different organizational structures, any person who has a certain number of employees to supervise was referred to as a library manager. Top managers were included in the research because they are the chief executives of academic libraries and perhaps the best source of evaluating the need for development of both middle and lower managers. Middle managers were also included because according to the Green Paper on Skills Development Strategy (1997:9) there has been a serious failure to address middle level competency in most organizations. This results in poor job performance on the part of middle level managers as they progress into higher-level management positions. Identification of development needs of middle level managers is therefore critical. Lower managers were also included in the research because more information on the skills and abilities of young librarians is needed as they move into managerial positions.

After the questionnaire was compiled, a pilot study was conducted. The results of the pilot study indicated that some of the questions needed to be changed for consistency. The final questionnaire was sent to the selected academic libraries. Twenty questionnaires were sent to each selected university library for distribution among appropriate managers.

\section{Results}

This section consist of response rate, demographics, rating of tasks in terms of importance, rating of development needs, rating of skills and competencies and other human resources management tasks. Library managers from five academic libraries responded to the questionnaire. Managers from one selected university library did not respond at all. Table I indicates the number of responses received from each selected academic library, which is $44(52.8 \%)$. 
Table I Response rate to questionnaires sent out $(\mathrm{N}=44)$

\begin{tabular}{ll}
\hline Institution & Responses (\%) \\
\hline University of South Africa (UNISA) & $14(70)$ \\
University of the North (UNIN) & $1 \mathrm{I}(55)$ \\
Rand Afrikaans Universiteit (RAU) & $8(40)$ \\
University of Venda (Univen) & $8(40)$ \\
University of Pretoria (UP) & $3(15)$ \\
University of North-West (UNW) & $0(0)$ \\
\hline Total & $\mathbf{4 4}(\mathbf{5 2 . 8 )}$ \\
\hline
\end{tabular}

The number of top, middle and lower managers in each selected library, the costs involved in postage, distance, and other factors might have affected the number of responses that were received.

\section{Demographics}

Out of forty-four responses that were received, 29(65.9\%) of the respondents were female and $15(34.1 \%)$ of them were males. These results (table 2) revealed that the library and information service profession in the selected academic libraries predominantly consists of female workers.

Table 2 Gender of respondents $N=44$

\begin{tabular}{lcccccc}
\hline \multicolumn{1}{c}{ Gender } & \multicolumn{5}{c}{ Frequency } & Total (\%) \\
\hline & UNIN & RAU & UP & UNIVEN & UNISA \\
Females & 7 & 2 & 1 & 2 & 3 & $29(65.9)$ \\
Males & 4 & 6 & 2 & 6 & 11 & $15(34)$ \\
\hline Total & II & $\mathbf{8}$ & $\mathbf{3}$ & $\mathbf{8}$ & 14 & $\mathbf{4 4}(100)$ \\
\hline
\end{tabular}

As pertains to age of the respondents, the largest number of library managers was in the age group between 40-49. Out of forty-four, $(15 ; 34.1 . \%)$ respondents were within this age group. Thirteen $(29.5 \%)$ respondents each were in the age groups 30-39 and 50-59 years. Only two (4.5. \%) of the respondents were within the age group of $18-29$ years and one (2.2. \%) respondent was within the age group of 60 years and older. When these results were analyzed to determine the management positions held by each age group it was found that the respondents who were in the majority (40-49) held middle level positions. Respondents whose age ranged between 50-59 occupied top management positions. This showed that most library managers occupying top management positions were reaching retirement age.

The largest group of respondents was those who had Masters in Library and Information Science with fourteen (31.8\%). Thirteen (29.5\%) respondents had Honors in Library and Information Science, followed by seven (I5.9\%) respondents who had a B. Bibl (Bachelor of Library Science) degree or a degree plus Higher/Postgraduate Diploma in Library and Information Science. Four respondents (9\%) had a Tecknikon Diploma in Library and Information Science. Three respondents $(6.8 \%)$ had a matric /school leaving certificate and two $(4.5 . \%)$ respondents had a Doctorate in Library and Information Science. One (2.2\%) of the respondents had another qualification, other than the abovementioned qualifications.

When these above results were analyzed to determine which positions the library managers held and what their level of qualifications were, it was found that, a large number of those who had Honours in Library and Information Science, occupied top management positions. This was contrary to expectations that those who had Masters degree would occupy top management positions, more so that they were in the majority.

As pertains to experience, the results showed that nineteen $(43.1 \%)$ respondents have been in the library and information profession for $10-19$ years. Thirteen (29.5\%) respondents have $20-29$ years experience. Eight (18.2\%) respondents had I-9 years experiences. Three (6.8. \%) respondents had 30-39 years' experience while one (2.2. \%) respondent had 40 and more years of experience. Eighteen of the respondents (40.9\%) had I-5 subordinates working under them. Ten (22\%) respondents had 6-10 subordinates; seven respondents (I5.9\%) have II-I5 subordinates, whilst five (1 I.3\%) respondents had 21 and more subordinates. Two respondents (4.5. \%) had 16-20 subordinates. Two other respondents $(4.5 \%)$ did not indicate how many subordinates were working under them. 
Rating of tasks in terms of importance

The respondents were asked to indicate how they rate human resources management tasks in terms of importance by indicating:

$\mathrm{I}=$ Not important at all;

2 = Not important;

3 = Important;

4 = Very important;

$5=$ No opinion

The results (table 3) revealed that most respondents' rated the tasks involved in utilizing and developing human resources (task \# I I-\# I5) highest and as the most important. These tasks included:

- Improving human relations with (40; 90.9\%)

- Motivating employees with (39;88.6\%)

- Conducting performance appraisals with $(36 ; 81.8 \%)$

- Delegating responsibilities among staff with $(34 ; 77.2 \%)$

The tasks that are involved in managing labour relations (task \# 16-\#20) were rated next in importance. These tasks included:

- Communicating with employees with (40; $90.9 \%)$

- Maintaining and improving working conditions with (34; 77.7\%)

- Understanding employment legislation with (3I; 70.4\%)

Table 3 Rating of tasks in terms of importance $(\mathrm{N}=4)$

\begin{tabular}{lllllll}
\hline Task No. & Task & I & $\mathbf{2}$ & $\mathbf{3}$ & $\mathbf{4}$ & $\mathbf{5}$ \\
\hline 1 & Formulating human resource strategy & 0 & 3 & 11 & 24 & 6 \\
2 & Conducting job analysis and design & 0 & 3 & 12 & 27 & 2 \\
3 & Writing job descriptions and specifications & 0 & 3 & 11 & 28 & 2 \\
4 & Assessing human resource management requirements & 0 & 3 & 11 & 28 & 2 \\
5 & Designing work rules and procedures & 0 & 1 & 12 & 30 & 1 \\
6 & Recruiting potential employees & 0 & 5 & 13 & 21 & 5 \\
7 & Evaluating the recruitment process & 0 & 5 & 16 & 19 & 4 \\
8 & Selecting and appointing new employees & 0 & 0 & 14 & 28 & 2 \\
9 & Achieving equity in the selecting process & 0 & 1 & 16 & 24 & 3 \\
10 & Introducing new employees to the library & 0 & 2 & 16 & 24 & 2 \\
11 & Motivating employees & 0 & 1 & 3 & 39 & 1 \\
12 & Improving human relations & 0 & 0 & 4 & 40 & 0 \\
13 & Conducting performance appraisals & 0 & 1 & 7 & 36 & 0 \\
14 & Evaluating training programmes for employees & 0 & 2 & 16 & 25 & 1 \\
15 & Delegating responsibilities among staff & 0 & 2 & 7 & 34 & 1 \\
16 & Understanding employment legislation & 0 & 1 & 12 & 31 & 0 \\
17 & Maintaining discipline among employees & 0 & 2 & 16 & 25 & 1 \\
18 & Handling employment grievances & 0 & 2 & 17 & 24 & 1 \\
19 & Communicating with employees & 0 & 0 & 4 & 40 & 0 \\
20 & Maintaining and improving working conditions & 0 & 2 & 7 & 34 & 1 \\
\hline & & & & & \\
\hline
\end{tabular}

The tasks involved in human resources planning (tasks \# I-\#5) were next, whilst the tasks involved in the provision (tasks \# 6-\# 10) of human resources were rated the least important.

Rating of training and development needs

In order to measure the training and development needs of library managers regarding listed human resource management tasks, the respondents were requested to tick:

$\mathrm{I}=$ No need at all,

$2=$ No need,

$3=$ Need,

$4=$ Strong need,

$5=$ No opinion or not applicable.

SA JnI Libs \& Info Sci 2005, 7I(I) 
Respondents indicated a "strong need" for training and development in conducting performance appraisals with twenty seven $(61.3 \%)$ respondents, followed by motivating employees with twenty one $(45 \%)$ respondents, followed by maintaining discipline among employees and handling employee grievances with nineteen $(43.1 \%)$ respondents each. Other tasks that the respondents had a strong need for training and development, understood employment legislation, communicating with employees and conducting job analysis and design with eighteen (40.9\%) respondents each.

Table 4 Rating of development needs $(\mathrm{N}=44)$

\begin{tabular}{lllllll}
\hline Task No. & Task & 1 & 2 & 3 & 4 & 5 \\
\hline 1 & Formulating human resource strategy & 0 & 1 & 18 & 14 & 8 \\
2 & Conducting job analysis and design & 0 & 4 & 13 & 18 & 6 \\
3 & Writing job descriptions and specifications & 0 & 7 & 16 & 16 & 3 \\
4 & Assessing human resource management requirements & 0 & 6 & 17 & 13 & 4 \\
5 & Designing work rules and procedures & 0 & 10 & 15 & 12 & 4 \\
6 & Recruiting potential employees & 1 & 9 & 16 & 9 & 6 \\
7 & Evaluating the recruitment process & 1 & 8 & 17 & 10 & 5 \\
8 & Selecting and appointing new employees & 1 & 9 & 15 & 11 & 6 \\
9 & Achieving equity in the selecting process & 0 & 10 & 11 & 15 & 5 \\
10 & Introducing new employees to the library & 2 & 14 & 9 & 8 & 8 \\
11 & Motivating employees & 1 & 3 & 15 & 21 & 1 \\
12 & Improving human relations & 1 & 5 & 15 & 20 & 1 \\
13 & Conducting performance appraisals & 0 & 6 & 8 & 27 & 2 \\
14 & Evaluating training programmes for employees & 0 & 11 & 15 & 13 & 1 \\
15 & Delegating responsibilities among staff & 2 & 11 & 12 & 16 & 1 \\
16 & Applying employment legislation & 0 & 4 & 16 & 18 & 1 \\
17 & Maintaining discipline among employees & 0 & 7 & 11 & 19 & 1 \\
18 & Handling employment grievances & 0 & 5 & 15 & 19 & 1 \\
19 & Communicating with employees & 1 & 10 & 11 & 18 & 0 \\
20 & Maintaining and improving working conditions & 0 & 6 & 15 & 15 & 13 \\
\hline
\end{tabular}

These results (Table 4) revealed that most respondents need training and development in tasks relating to utilizing and developing human resources, followed by tasks relating to managing labour and employment relations. The tasks relating to human resource planning are next, and the tasks relating to human resource provision were rated lowest.

Regarding Skills and competencies for effective management of library staff, the respondents were requested to indicate skills and competencies they need to develop or enhance in order to manage staff effectively. They were requested to agree or disagree with the statement: "I need development on the following skills and competencies in order to improve my ability to manage library staff effectively". The following scale was used to determine this:

$\mathrm{I}=$ strongly disagree,

2 = disagree,

$3=$ agree

$4=$ strongly agree,

$5=$ no opinion.

Not all respondents rated all the listed tasks. The results (table 5) showed that the majority of the respondents "strongly agree" that they need developing their skills and competencies in managing staff effectively. Twenty-four (60\%) respondents indicated that they "strongly agree" they need to develop skills and competencies in managing change and team building. Twenty-one (52,5\%) respondents indicated that they "strongly agree" they need to develop their leadership skills, whilst twenty (50\%) respondents indicated a "strongly agree" they need to develop their communication skills.

Some of the skills that most respondents indicated a need for development, but not strongly were time management and mentoring skills with twenty three $(57,5 \%)$ and twenty one $(52.5 \%)$ respondents respectively. Respondents who indicated that they need training and development in policy formulation and facilitation were next with seventeen ( $45 \%$ ) respondents each. 
Table 5 Rating of skills and competencies $(\mathrm{N}=44)$

\begin{tabular}{lllllll}
\hline No. & Skills \& \& competencies & I & $\mathbf{2}$ & $\mathbf{3}$ & $\mathbf{4}$ & $\mathbf{5}$ \\
\hline 1 & Communication & 3 & 5 & 12 & 20 & 1 \\
2 & Mentoring & 0 & 6 & 21 & 14 & 0 \\
3 & Motivation & 0 & 6 & 16 & 19 & 9 \\
4 & Team building & 0 & 4 & 12 & 24 & 1 \\
5 & Time management & 0 & 3 & 23 & 14 & 1 \\
6 & Assertiveness & 0 & 8 & 16 & 16 & 0 \\
7 & Policy formulation & 0 & 5 & 17 & 15 & 2 \\
8 & Facilitating & 0 & 5 & 17 & 15 & 1 \\
9 & Managing change & 1 & 3 & 13 & 24 & 0 \\
10 & Leadership & 1 & 3 & 16 & 21 & 0 \\
\hline
\end{tabular}

Some respondents $(5 ; 40 \%)$ indicated a need to develop their assertiveness skills to manage library staff effectively.

Other human resources management tasks

In this section the respondents were asked to list any other human resources management tasks that they feel are important and they would like to improve their performance in, but were not included in the questionnaire. Only five respondents responded to this question. One named counseling, conflict resolution and negotiation. The other respondent mentioned delegation even if this was included in the questionnaire. The third respondent included training the trainers and performance management. The fourth respondent mentioned human resource planning even if this was included as one of the main activities in human resources management. The last respondent made a comment that their university has a human resource department to do most of the human resources management activities and tasks, like developing plans and procedures and recruitment. The respondent indicated that they receive performance appraisal forms with instructions to do it.

\section{Discussion of results}

Not much significance can be attached to the results for the response rate, as it was not known how many staff members were working in these libraries and how many of them occupy management positions on any level. The aim of this study was to use only a sample of the population of academic libraries in the region and to establish if trends regarding the problem under investigation can be discovered. Forty-four responses in all were received and deductions from this number should be as sufficient to allow the researcher to draw conclusions regarding trends valid for the selected population.

The results showed that the library and information profession in the selected academic libraries is female dominated in terms of numbers. Despite this dominance, most women in academic libraries were still occupying middle and lower level management positions. In the five academic libraries that participated, only one woman out of twenty-nine occupied the position of director and five were at deputy director or deputy librarian level. One may agree with Erasmus' (1998:76) observation that, although managers accept affirmative action in relation to blacks, it is not the case regarding women in South African organizations. Many people continue to see female and male differences as having implications for work performance abilities. Women managers are still subject to gender-based barriers and discrimination even in organizations where they are in the majority.

Yadavalli (1999: 26) identified aging managers occupying top management positions in the organizations as one of the major challenges posing a serious threat to the workforce in the future. Training and development of the managers occupying middle and lower management positions is therefore essential in order to replace the aging managers. Training of middle level competencies is also emphasized in the Green Paper on Skills Development Strategy in South Africa (1997: I). Despite these sentiments, the results of this study revealed that most library directors occupying top-level positions were reaching retirement age. Only few academic libraries already had staff members between the ages of forty and forty-nine and none between the ages 30-39 who occupy top management positions. This will create a vacuum in the future, when these managers reach retirement age. No one with experience will be available to take their place.

Most of the respondents had postgraduate qualifications in Library and Information Science. This reflects formal education only, sometimes acquired a long time ago, perhaps in courses where little attention was given to management issues, because the overwhelming content which have to be covered by curricula, especially in undergraduate studies. Human resources management as such, might be a new development, which was perhaps not even touched upon, in most undergraduate courses. 
Experience is also equally important in determining the management development needs of managers. Management development needs of library managers, who are more experienced, differ from library managers with less experience. In this study, the results showed that most managers had extensive experience in academic libraries, especially those in top and middle level positions. Even if a large number of respondents have experience, they have indicated a need for training and development in specific human resource management tasks.

The number of library staff or subordinates each manager supervises can also have an influence on the management abilities of library managers. The library manager with a large number of staff directly under him or her may experience problems in for example, communicating with employees. Differences in terms of values, abilities, skills, personalities, attitudes etc., may have an impact on the management abilities of a manager. This is however dependant on the size of the academic library.

As pertains to the rating of tasks, the results showed that the respondents rated all the tasks listed as important. Tasks relating to utilizing and development of human resources were rated highest, followed by tasks related to managing labour and employment relations. Tasks that are involved in planning were rated third, followed by those involved in human resources provision. Library managers' rated tasks related to human resources utilization and development highest, probably because they should ensure that the skills and competencies of library staff under them are continuously enhanced or developed. The Working Group on Libraries and Information Technology: National Commission on Higher Education, 1996: 1-7) emphasized that investment in human resources training and development is the key factor in raising the quality of library and information services. It is emphasized that poor levels of service in a library because of inadequate staff training and development, may lead to an apparent lowering of user demand, and hence the perception in institutions that increased overall funding support may be unnecessary.

The tasks involved in managing labour and employment relations were rated second in importance. These results revealed that human resource management today requires not only strong interpersonal relations, but also an understanding and appreciation of employment legislation. Library managers need training and development in managing labour and employment relations because this area did not receive necessary attention in the past. It is important that they know more about this aspect because it affects all the human resources management functions, from recruitment to communicating with employees. Managers need to know more about dealing with aspects such as maintaining discipline, handling grievances, and managing conflicts among staff in the library. The costs of lack of knowledge on these aspects are extremely high, since this might lead to poor service levels, low productivity, court cases, strikes, violence, bad public image etc.

When asked to prioritize these tasks, managing labour and employment relations were put first, followed by tasks involved in utilizing and development and then planning, followed by provision. Although the sequence differs, there is not really much difference between the ratings of the different tasks. All tasks were regarded as important, but the order and the percentages changed when respondents were asked to prioritize the tasks. The respondents also showed they need to develop their performance need in matters relating to handling of staff such as performance appraisal, motivation and improving working conditions and human relations. Performance appraisal is the key management tool to ensure that:

- employees know what is expected of them;

- managers know whether the employee's performance is achieving required objectives;

- poor performance is identified and improved, and

- good performance is recognized and rewarded

Performance appraisal is important to library managers, because it provides them with information on wage and salary decisions, promotions, dismissals, and training and development needs. On the other hand it provides employees with feedback as to how well they are doing in their jobs, specifying their weaknesses and strengths.

As pertains to motivation, people work in organizations because they need money in order to make a living. In order to motivate them to work harder, the best way is to offer them more money. The problem with academic libraries is that they don't have enough money to compensate their employees adequately. Library managers are therefore faced with a challenge to motivate their employees to work harder without promising them money. Library managers who do not want their staff to be lost to other organizations should therefore demonstrate that they are worthy of respect and have personal integrity. This calls for the need for managers to maintain good working relations with staff, which was also rated highest by most respondents.

Looking at these needs, it is clear that most managers in selected university libraries need training and development in human resources management tasks that they are directly involved in, rather than tasks that can be delegated to the human resources department within the university. They need training and development in human resources management tasks that deal with interpersonal relations between the manager and staff member than on tasks that are administrative in nature. 
Library managers also mentioned managing change, teambuilding and communication as important skills and competencies that they would like to enhance. Various factors such as changes in educational policy by government, financial constraints, staff and student profiles, rising costs of library materials and advances in information technology compel academic libraries to make drastic changes in order to adapt to these new situations. With the emergence of new academic structures in higher education, library managers also need to learn how to build and develop work teams that would meet the needs of their clients. Library managers also expressed a need for training and development in communication because this plays a central role for interactions between individuals, between members of groups and between members of staff in an organization. Communication is integral for any relationship.

\section{Conclusions}

This study showed that most of the library managers who responded rated almost all human resources management tasks as important and would like to receive more training and development in performing those tasks. They also indicated that there are some other skills and competencies that they need to enhance in order to manage their staff effectively. Management development programme for library managers in selected academic libraries could be designed and developed on the basis of this needs. The general recommendation made is that, the critical human resources management activities and tasks, as well as skills and competencies, identified in this study need careful and consistent attention if the goals and objectives of the university libraries are to be met.

Further research projects can be undertaken to determine if the management development needs of library managers remain the same in future. Training and development needs of library managers will not remain static, mainly because they are influenced by changes in the environment within which library managers operate. New legislation may be passed; new workplace practices and new management techniques may be developed. Further research projects can also be undertaken to determine management development needs of library managers in other regions in South Africa.

\section{References}

De Beer, A. (et al) (1998). Focus on supervision in general management. Cape Town. Juta.

Brindley, L. (1987). Management development for information professionals of the future. Aslib Proceedings, 39 (9): $235-243$

Corral, S. (1994). Management development in academic libraries and the joint funding council's libraries review. British Journal of Academic Librarianship, 9 (3): 209-220

Corral, S. (1995). Academic libraries in the information age. New Library World, 96 (I I): 35-42

Erasmus B.J. (1998). South African human resources management: Theory and practice. Cape Town: Juta

Erasmus, B.J. (1997). Transforming HRD: keystone to success in organizations: Management Today, 13 (8): $20-30$

Erasmus, B.J. \& Van Wyk, P.S. ( 1999). Training management in South Africa, $2^{\text {nd }}$ ed. Johannesburg: International Thompson Publishing GAELIC Profile. (2002) [Online] Available at: http://miscweb.mics.co.za/about.html (accessed on I0th June 2004)

Graham .J.K. \& Mihal, W.L. (1986). Can your management development needs surveys be trusted? Training and development Journal, 40 (3): 38-42

Kinnel, M. (1996). Management development for information professionals. Aslib proceedings, 48 (9): 209-2। 4

McCabe, G.B. \& Person R.J. (1995). Academic Libraries: Their rationale and role in American Higher Education. London: Greenwood press

National Commission on Higher Education: Working Group on Libraries and Information Technology. 1996. Policy, Planning and Cooperation: Smart solutions for Information Provision - A working Group Report. Pretoria: HSRC

Ochai, A. (1985). Management development needs of library managers in university libraries in Nigeria. Library and Information Science Research, 7 (4): 357-368.

Rowley J. (1995) Management Development: New agenda for information professionals. Library Management, I6 (I): 5 - I0

South Africa. Basic Conditions of Employment Act (No 75 of 1997). Pretoria: Government Printer

South Africa. Department of Labour. (1997) Green paper on skills development strategy. Pretoria: Government Printer

South Africa. Employment Equity Act (No. 55 of 1998). Pretoria: Government Printer

South Africa. Labour Relations Act (No. 66 of 1995). Pretoria: Government Printer

South Africa. Republic of South Africa Constitution Act (No. 108 of 1996). Pretoria: Government Printer

South Africa. Skills Development Act (No. 97 of 1998). Pretoria: Government Printer

Yadavalli, L. (1999). Labour: Problems in the next century. Management Today, I5 (4): 25-27 